\title{
Antithrombotic Therapies in COVID-19 Disease: a Systematic Review
}

\author{
Edward Maldonado, $\mathrm{MD}^{7}$, Derrick Tao, $\mathrm{MD}^{7}$, and Katherine Mackey, MD, MPP 2 \\ 'Department of Medicine, Oregon Health \& Science University, Portland, OR, USA; '2Department of Veterans Affairs Evidence Synthesis Program \\ (ESP), VA Portland Healthcare System, Portland, OR, USA.
}

BACKGROUND: Infection with coronavirus SARS-CoV-2, causing COVID-19 disease, leads to inflammation and a prothrombotic state.

OBJECTIVE: This rapid systematic review aims to synthesize evidence on thromboembolism incidence and outcomes with antithrombotic therapies in COVID-19.

DATA SOURCES: We searched MEDLINE (Ovid), Cochrane Rapid Reviews, PROSPERO, and the WHO COVID-19 Database from January 1, 2003, to April 22, 2020, for studies meeting pre-specified inclusion criteria. STUDY SELECTION, DATA EXTRACTION, AND SYNTHESIS: One investigator identified articles for inclusion, abstracted data, and performed quality assessment, with second reviewer checking.

RESULTS: Incidence of thromboembolism among hospitalized patients with COVID-19 ranged from 25 to $53 \%$ in 4 retrospective series. We identified 3 studies ( 1 retrospective cohort study, 1 prospective uncontrolled observational study, and 1 case series) examining outcomes among COVID-19 patients who received antithrombotic therapies. These studies all included different interventions (thromboprophylaxis with unfractionated heparin (UFH) or low molecular-weight heparin (LMWH); an intensive thromboprophylaxis protocol with $\mathrm{LMWH}$, antithrombin, and clopidogrel; and salvage therapy with tissue plasminogen activator and heparin). These studies are overall poor quality due to methodological limitations including unclear patient selection protocols, lack of reporting or adjustment for patient baseline characteristics, inadequate duration of follow-up, and partial reporting of outcomes.

CONCLUSIONS: New evidence on thromboembolism in COVID-19 does not warrant a change in current guidance on thromboprophylaxis among hospitalized patients. Prospective trials of antithrombotic treatment strategies among patients with COVID-19 are urgently needed.

KEY WORDS: COVID-19; anticoagulants; thromboembolism; sepsis.

J Gen Intern Med 35(9):2698-706

DOI: $10.1007 / \mathrm{s} 11606-020-05906-y$

(C) Society ofGeneral InternalMedicine (This is aU.S. government work and not under copyright protection in the U.S.; foreign copyright protection may apply) 2020

Received April 29, 2020

Accepted May 4, 2020

Published online June 17, 2020

\section{INTRODUCTION}

Infection with the novel coronavirus SARS-CoV-2, which causes the disease COVID-19, can lead to inflammation and a prothrombotic state characterized by elevations in D-dimer, fibrin/fibrinogen degradation products, and fibrinogen. ${ }^{1,2}$ These lab abnormalities have been proposed as markers of severe disease and worse prognosis. ${ }^{1,3}$ Although the cooccurrence of inflammation and hypercoagulability in sepsis has previously been recognized, including during the severe acute respiratory syndrome (SARS) epidemic of 2002-2003, clinicians and researchers studying COVID-19 are asking whether the risk of venous and arterial thromboembolism is higher in COVID-19 than with other sources of infection and whether COVID-19 patients would benefit from intensified antithrombotic therapies. $^{4-7}$ A retrospective analysis of 1026 patients with COVID-19 in China found that 40\% (407 patients) had a Padua prediction score $\geq 4$ indicating higher risk for venous thromboembolism (VTE). ${ }^{8}$

Clinical scenarios in which intensified antithrombotic therapies for COVID-19 patients have been proposed include extending prophylactic dosing of unfractionated heparin (UFH) or low molecular weight heparin (LMWH) once patients discharge home, using higher doses of thromboprophylaxis for hospitalized patients, and empiric use of therapeutic anticoagulation and thrombolytics as a salvage approach when critically ill patients appear to be clinically deteriorating. ${ }^{7,9}$ The role of antithrombotic therapies in the latter scenario is based on speculation that patients with COVID-19 may worsen due to deposition of fibrin in the airspaces and lung parenchyma in addition to fibrin-platelet microthrombi in the pulmonary vasculature. ${ }^{9}$ Of note, broader use of vitamin $\mathrm{K}$ antagonists and direct oral anticoagulants (DOACs) in COVID-19 treatment has generated less interest due to potential drug-drug interactions with antiviral therapies. $^{2,10}$

Currently, the World Health Organization (WHO) recommends prophylactic dose heparin or LMWH for prevention of VTE in hospitalized adults and adolescents with severe COVID-19 disease except if contraindicated. ${ }^{11}$ This guidance is also referenced by the US Centers for Disease Control and Prevention (CDC) and Department of Defense (DoD). ${ }^{12,} 13$ Similarly, the International Society of Thrombosis and Haemostasis (ISTH) recommends prophylactic dosing of LMWH 
Table 1 Current Guideline Recommendations

\begin{tabular}{|c|c|c|c|}
\hline Source & Recommendation & $\begin{array}{l}\text { Date } \\
\text { published }\end{array}$ & $\begin{array}{l}\text { Date } \\
\text { accessed }\end{array}$ \\
\hline \multicolumn{4}{|l|}{ Guidance specific to COVID-19 } \\
\hline World Health Organization ${ }^{11}$ & $\begin{array}{l}\text { Use pharmacological prophylaxis (LMWH [preferred if available] or heparin } \\
5000 \text { units subcutaneously twice daily) in adolescents and adults without } \\
\text { contraindications. For those with contraindications, use mechanical prophylaxis } \\
\text { (intermittent pneumatic compression devices). }\end{array}$ & $3-13-2020$ & $4-12-2020$ \\
\hline $\begin{array}{l}\text { International Society of } \\
\text { Thrombosis and Haemostasis } \\
\end{array}$ & $\begin{array}{l}\text { Consider prophylactic dose LMWH in all patients (including non-critically ill) } \\
\text { who require hospital admission for COVID-19 infection, in the absence of any } \\
\text { contraindications. }\end{array}$ & $3-25-2020$ & $4-12-2020$ \\
\hline $\begin{array}{l}\text { Centers for Disease Control and } \\
\text { Prevention }\end{array}$ & $\begin{array}{l}\text { No specific comment on anticoagulation in COVID-19 patients; refers to WHO } \\
\text { guidance }\end{array}$ & $4-3-2020$ & $4-12-2020$ \\
\hline Department of Defense ${ }^{13}$ & $\begin{array}{l}\text { No specific comment on anticoagulation in COVID-19 patients; refers to WHO } \\
\text { guidance }\end{array}$ & $3-23-2020$ & $4-12-2020$ \\
\hline $\begin{array}{l}\text { Infectious Disease Society of } \\
\text { America }^{19}\end{array}$ & No specific comment on anticoagulation in COVID-19 patients & $4-11-2020$ & $4-12-2020$ \\
\hline $\begin{array}{l}\text { The Italian Society on } \\
\text { Thrombosis and Haemostasis }{ }^{10}\end{array}$ & $\begin{array}{l}\text { - Use LMWH, UFH, or fondaparinux at doses indicated for prophylaxis of VTE } \\
\text { in all COVID-19 hospitalized patients; patients with anticoagulant contra- } \\
\text { indications should be treated with limb compression. } \\
\text { - Thromboprophylaxis should be administered for the entire hospital stay and } \\
\text { maintained at home for } 7-14 \text { days after hospital discharge or in the pre-hospital } \\
\text { phase, in case of pre-existing or persisting VTE risk factors. } \\
\text { - The use of intermediate-dose LMWH (i.e., enoxaparin } 4000 \text { IU subcutaneously } \\
\text { every } 12 \text { h) can be considered on an individual basis in patients with multiple risk } \\
\text { factors for VTE. } \\
\text { - Use of therapeutic doses of UFH or LMWH is not recommended as a standard } \\
\text { treatment. }\end{array}$ & $4-8-2020$ & $4-14-2020$ \\
\hline \multicolumn{4}{|c|}{ Guidance published prior to COVID-19 } \\
\hline $\begin{array}{l}\text { American Society of } \\
\text { Hematology }\end{array}$ & $\begin{array}{l}\text { Use UFH, LMWH, or fondaparinux rather than no parenteral anticoagulant in } \\
\text { acutely ill medical patients and UFH or LMWH in critically ill medical patients. }\end{array}$ & $11-2018$ & $4-12-2020$ \\
\hline $\begin{array}{l}\text { Society of Critical Care } \\
\text { Medicine }\end{array}$ & $\begin{array}{l}\text { Recommends against the use of antithrombin for the treatment of sepsis and } \\
\text { septic shock. No recommendation regarding the use of thrombomodulin or } \\
\text { heparin for the treatment of sepsis or septic shock }\end{array}$ & 03-2020 & $4-12-2020$ \\
\hline
\end{tabular}

for all hospitalized patients with COVID-19 unless otherwise contraindicated. ${ }^{14}$ These recommendations are consistent with 2018 guidelines from the American Society of Hematology (ASH) recommending thromboprophylaxis for acutely and critically ill hospitalized patients with LMWH, UFH, or fondaparinux. ${ }^{15}$ ASH guidance is based on evidence from systematic reviews and primary studies of thromboprophylaxis in hospitalized patients as well as a trial of fondaparinux compared to no anticoagulation. ${ }^{15}$

For patients with COVID-19, the Italian Society on Thrombosis and Haemostasis ${ }^{10}$ and a consensus statement recently published in the Journal of the American College of Cardiology written by an international collaborative ${ }^{16}$ both recommend consideration of extended thromboprophylaxis postdischarge for patients at higher risk of VTE and cite insufficient evidence to recommend empiric use of therapeutic dose UFH and LMWH. These recommendations represent a change compared to 2018 ASH guidelines, which do not recommend extended thromboprophylaxis post-hospital discharge, ${ }^{15}$ a strategy that previously has been found to have a narrow risk-benefit ratio even in patients at higher risk for VTE. ${ }^{17}$ The Italian Society on Thrombosis and Haemostasis also recommends considering intermediate (higher) dosing of thromboprophylaxis for hospitalized patients. ${ }^{10}$

In the past, other agents have been proposed to mediate the prothrombotic state in sepsis including antithrombin, thrombomodulin, recombinant activated protein $\mathrm{C}$, and heparin. ${ }^{4}$ The Society of Critical Care Medicine's 2016 Surviving
Sepsis Campaign (SCC) guidelines recommend against the use of antithrombin based on a trial showing lack of benefit and increased bleeding risk. ${ }^{18}$ These guidelines make no recommendation regarding thrombomodulin or heparin. Table 1 presents a summary of current guidelines regarding thromboprophylaxis in COVID-19 and relevant guidelines published before the onset of COVID-19.

The aim of this rapid systematic review is to synthesize evidence on the incidence of thromboembolism in patients with COVID-19 and whether antithrombotic therapies improve outcomes.

\section{METHODS}

This review is based on a report ${ }^{20}$ by the VA Evidence Synthesis Program Coordinating Center conducted for the US Department of Veterans Affairs Health Services Research and Development (HSR\&D) to help inform VA clinical policies and practice. This review was conducted and reported using standard systematic review methods and guidelines. ${ }^{21,}$ 22 The review is not yet registered with PROSPERO.

We systematically searched MEDLINE (Ovid), Cochrane Rapid Reviews, PROSPERO, and the World Health Organization (WHO) COVID-19 Database from January 1, 2003, to April 22, 2020 (see supplemental materials for our full search strategy). Additional citations were identified from handsearching reference lists and consultation with content experts. 
We also searched for unpublished, ongoing, planned, or recently completed studies on clinicaltrials.gov. We included studies of adults with COVID-19 that examined the incidence of thromboembolic events and studies that examined patient outcomes with use of antithrombotic therapies. We broadly defined thromboembolic events to encompass deep vein thrombosis (DVT), acute pulmonary embolism (PE), myocardial infarction, ischemic stroke, and other systemic arterial thromboembolism. We also broadly defined antithrombotic agents to include anticoagulation therapies (UFH, LMWH, DOACs), tissue plasminogen activator (tPA), and antiplatelet agents. We did not limit our selection criteria by language. We excluded case reports and case series of less than 3 patients. Study selection, data abstraction, and quality assessment were conducted by one investigator and checked by another. All disagreements were resolved by consensus or review by a third investigator.

For observational studies with control groups, we used Cochrane's ROBINS-I tool ${ }^{23}$ to evaluate the potential for bias from participant selection, classification of interventions, departure from intended interventions, measurement of outcomes, confounding, and missing/unreported data. Overall bias ratings range from low, unclear, to high risk of bias. For observational studies without control groups, we adapted criteria from ROBINS-I as well as the CARE Checklist ${ }^{24}$ and focused on the quality of reporting, with ratings ranging from not reported, partly reported, mostly reported, to well reported.

We used the GRADE framework ${ }^{25}$ to evaluate the quality of the body of evidence. This framework considers study limitations (risk of bias), consistency of results, directness, and precision of the evidence. Ratings typically range from high to very low, reflecting our confidence that the evidence reflects the true effect. We synthesized evidence qualitatively.

\section{RESULTS}

The PRISMA ${ }^{22}$ flowchart (Fig. 1) summarizes the results of the search and study selection processes. Among 345 potentially relevant citations, we included 7 studies (1 retrospective cohort, 1 prospective uncontrolled observational study, and 5 retrospective series).

\section{Thromboembolism Incidence Among Patients with COVID-19 (Table 2)}

Incidence of thromboembolism among hospitalized patients with COVID-19 ranged from 25 to $53 \%$ in 4 retrospective series ( 2 from China ${ }^{26,28} ; 2$ from Europe ${ }^{29,31}$ ). The largest of these studies, a multi-center study of 184 hospitalized patients with COVID-19 in the Netherlands, ${ }^{29}$ found that the cumulative incidence of a composite outcome of acute PE, DVT, ischemic stroke, myocardial infarction, or systemic arterial embolism was $31 \%$ (95\% CI 20-41\%). Approximately $14 \%$ of patients (25/184) had CT-confirmed PE, 1.6\% (3/184) had ultrasound-confirmed venous thromboembolic event (including DVT), and 1.6\% (3/184) had ischemic stroke (classified as arterial thrombotic event). Notably, all patients received thromboprophylaxis, although dose and frequency varied depending on the institution (from nadroparin 2850 IU daily up to $5700 \mathrm{IU}$ twice a day). All patients $>100 \mathrm{~kg}$ received at least nadroparin 5700 IU daily. Coagulopathy, defined as spontaneous prolongation of prothrombin time $>3 \mathrm{~s}$ or activated partial thromboplastin time $>5 \mathrm{~s}$, (adjusted hazard ratio (aHR) 4.1, 95\% CI 1.9-9.1) and age (aHR 1.05 per year, 95\% CI 1.004-1.01) were independent predictors of thrombotic complications.

This study has several important limitations. Baseline patient characteristics, such as active malignancy, were not reported and could have influenced results. Approximately $2.7 \%(5 / 184)$ had active malignancy prior to hospital admission, and $9.2 \%$ of patients (17/1840) were already on therapeutic anticoagulation at admission (without indications reported). Additionally, it is unclear how thromboembolism incidence rates may have been affected by variable thromboprophylaxis dosing among the 3 institutions and a change in dosing protocols at 2 institutions during the observation period. Lastly, the length of follow-up was inadequate to evaluate the true incidence of thromboembolism, as $76 \%$ of patients $(139 / 184)$ remained in the ICU at the end of the observation period, likely underestimating incidence rates.

Two retrospective series ${ }^{26,} 28$ examined VTE incidence rates in hospitalized patients with COVID-19 in China. In one study, $25 \%$ of patients (20/81) with COVID-19 at a single hospital were diagnosed with lower extremity DVT. ${ }^{26}$ Comparison of the DVT and non-DVT groups showed that DVT was associated with older age $(68.4 \pm 0.1$ vs. $57.1 \pm 14.3$ years; $p<0.001)$, degree of lymphopenia $(0.8 \pm 0.4$ vs. $1.3 \pm 0.6 \times$ $109 / \mathrm{L} ; p<0.001)$, increased aPTT ( $39.9 \pm 6.4$ vs. $35.6 \pm 4.5 \mathrm{~s}$; $p=0.001)$, and elevated D-dimer $(5.2 \pm 3.0$ vs. $0.8 \pm 1.2 \mu \mathrm{g} /$ $\mathrm{mL}$ ). Patients had baseline co-morbidities including hypertension $(20 / 81 ; 25 \%)$, diabetes $(8 / 81 ; 10 \%)$, coronary artery disease $(10 / 81 ; 12 \%)$, and inhaled tobacco use $(45 / 81 ; 41 \%)$, but the study does not adjust for potential differences in baseline characteristics between patients who developed thromboembolism and those who did not. Also, because $11 \%$ of patients remained hospitalized at the end of the observation period, the true incidence of DVT during hospitalization could be underestimated. In the other retrospective series of 25 hospitalized patients with COVID-19 in China, 40\% (10/ 25 ) of patients met criteria for acute pulmonary embolism. ${ }^{28}$ This study also has several limitations including unclear selection criteria for the group of 25 patients among a cohort of 1008 hospitalized patients. Also, approximately 80\% (20/25) of patients were treated with LMWH $(0.6 \mathrm{mg} / \mathrm{kg}$ twice daily) regardless of the occurrence of a thrombotic event. However, the study does not report whether the patients who were treated with LMWH were at higher risk for VTE or had other baseline characteristics that differed from patients who did not receive $\mathrm{LMWH}$ 


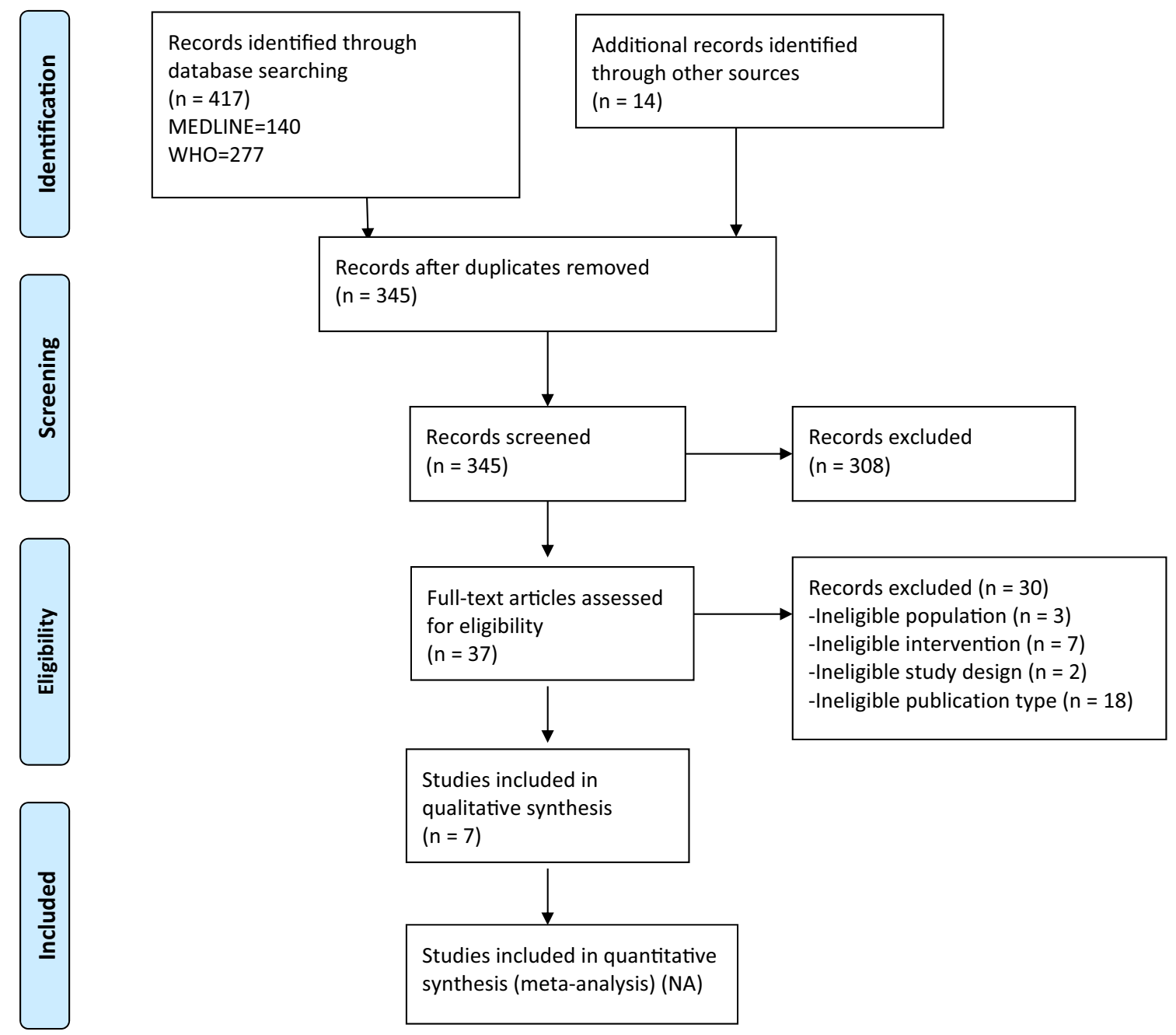

Fig. 1 The PRISMA flowchart showing the results of the search and study selection processes.

A fourth retrospective series of 30 hospitalized patients with COVID-19 in a vascular surgery unit in Italy found that 53\% patients (16/30) had ultrasound-confirmed lower or upper extremity DVT, ${ }^{31}$ but this study also has several limitations including unclear protocols for patient selection, lack of patient baseline co-morbidity data, lack of data regarding use of thromboprophylaxis, and unreported follow-up duration.

\section{Antithrombotic Treatments and Patient Outcomes in COVID-19 Disease (Table 2)}

We identified 3 studies (1 retrospective cohort study, ${ }^{30} 1$ prospective uncontrolled observational study, ${ }^{32}$ and 1 case series) ${ }^{27}$ examining outcomes among COVID-19 patients who received antithrombotic therapies.

In a single-center, retrospective cohort study of 449 hospitalized patients with severe COVID-19 disease in China, ${ }^{30}$ $22 \%(99 / 449)$ of patients received thromboprophylaxis (94 received LMWH, 5 received UFH). Mortality at 28 days was
$29.8 \%$ (134 patients) overall, with no difference between the 2 groups. A subgroup analysis found lower mortality with heparin treatment in patients who had sepsis-induced coagulopathy (SIC) scores $\geq 4(40.0 \%$ vs. $64.2 \%, p=0.029)$ and Ddimer $\geq 3.0 \mu \mathrm{g} / \mathrm{mL}$ (sixfold upper limit of normal) (32.8\% vs. $52.4 \%, p=0.017$ ) but whether this subgroup analysis was prespecified is unclear. An important limitation of this study is low applicability to settings and regions in which thromboprophylaxis is already standard of care in acute and critically ill patients. Additional limitations include lack of data regarding patient baseline comorbidities and reasons why some patients received thromboprophylaxis and others did not. Finally, the study states that bleeding events were "unusual and commonly mild" but does not provide more detail regarding adverse events associated with thromboprophylaxis.

In another single-center, prospective series from Italy, 16 critically ill mechanically ventilated patients with COVID-19 and acute respiratory distress syndrome (ARDS) were treated with a thromboprophylaxis protocol of LMWH 6000 IU twice 
Table 2 Published/Released Studies of VTE Incidence Among COVID-19 Patients and Antithrombotic Therapy

\begin{tabular}{|c|c|c|c|c|c|}
\hline $\begin{array}{l}\text { Author, year, } \\
\text { study design, } \\
\text { country }\end{array}$ & Dates & $\begin{array}{l}\text { Number } \\
\text { of cases }\end{array}$ & Patient characteristics & Results & $\begin{array}{l}\text { Quality assessment and } \\
\text { major limitations }\end{array}$ \\
\hline
\end{tabular}

Question 1: In patients with COVID-19, what is the incidence of thromboembolism?

Chen 2020, ${ }^{28} \quad$ January $2020-n=25 \quad$ Age (median): 65 years 10/25 (40\%) CT-confirmed

Retrospective February 2020

series, China

$\begin{array}{ll}\text { Cui 2020, } & \text { January } 30- \\ \text { Retrospective } & \text { March 22, 2020 }\end{array}$

series, China

- Gender (\% male): 60

- Comorbidities (\%):

hypertension 40 ,

diabetes 20 ,

cardiovascular disease

16, smoking 24

- Prior DVT (\%): 4

- Age (mean): 59.9 years

- Gender (\% male): 46

- Comorbidities (\%):

Hypertension 25 ,

diabetes 10 , coronary

acute pulmonary embolism (PE)

artery disease 12 ,

smoking 43

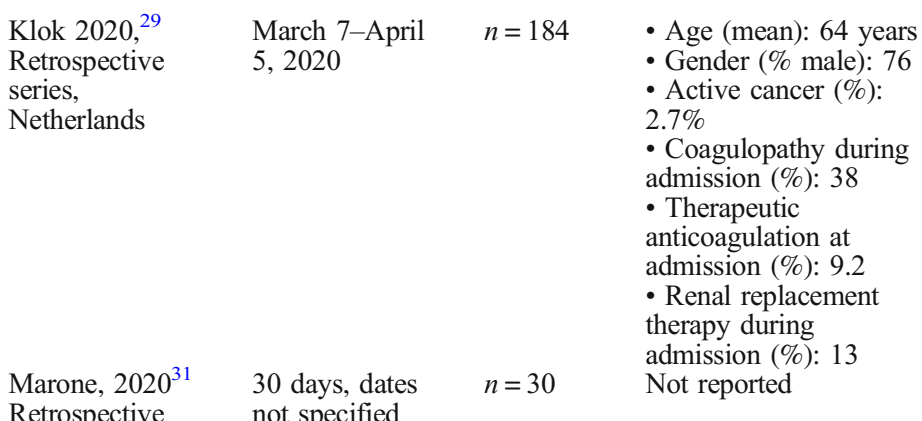

series, Italy
$31 \%(95 \%$ CI $20-41 \%)$

cumulative incidence of a composite outcome of thromboembolic phenomena (acute PE, DVT, ischemic stroke, myocardial infarction, or systemic arterial embolism)

$16 / 30(53 \%)$ incidence of ultrasound-confirmed lower and upper extremity DVT

Question 2: In patients with COVID-19 disease, do antithrombotic therapies improve outcomes?

Prospective

least 7-14 days

follow up period

uncontrolled

observational study, Italy

$$
n=449
$$

February 13, 2020

Retrospective cohort, China
- Intubation time at baseline (days): 7 BMI > 30: 5 , diabetes 20 , cardiovascular disease 16 , tobacco use 24 , prior DVT 4
- Gender (\% male): 94 - Comorbidities (\%):

thromboprophylaxis protocol with LMWH, antithrombin and clopidogrel

- 0/16 (0\%) major thromboembolic events

- 7/16 (43.7\%) mortality during observation period

- 6/16 (37.5\%) discharged from intensive care

- 16/16 (100\%) with pro-coagulation profile at baseline (elevated fibrinogen and D-dimer); 9/16 (56.3\%) with progression toward normal coagulation profile (decreased clot stiffness, platelet contribution to clot stiffness, and fibrinogen contribution to overall clot stiffness), after increased thromboprophylaxis at day 14

- Use of UFH or LMWH thromboprophylaxis - 134/449 (29.8\%) 28-day mortality

- Gender (\% male): 60

- Comorbidities (\%): hypertension 40 diabetes 21 , cardiovascular disease 9.1

Wang, $2020^{27}$

NR

$n=3$
Case 1: 75-year-old man with hypertension, hyperlipidemia, type 2
- Poor quality, partly reported - Unclear protocols for patient selection

- Lack of patient baseline comorbidity data and use of thromboprophylaxis in some patients

- Poor quality, partly reported

- Results not adjusted for patient baseline characteristics

- Inadequate length of follow-up to estimate true incidence of thromboembolic events $(11 \%$ of patients remained hospitalized at the end of the observation period) - Poor quality, partly reported

- Results not adjusted for patient baseline characteristics or changes in thromboprophylaxis dosing during study period

- Inadequate length of follow-up to estimate true incidence of thromboembolic events $(76 \%$ of patients remained hospitalized at the end of the observation period)

- Poor quality, partly reported

- Unclear protocols for patient selection

- Lack of patient baseline co-morbidity data

- Lack of data regarding use of thromboprophylaxis

- Unreported follow-up duration

- Poor quality

- Unclear protocols for patient selection

- Results not adjusted for patient baseline characteristics or other treatments received

- Partly reported adverse events

\footnotetext{
- Poor quality

- Low applicability to settings where thromboprophylaxis is standard of care for

hospitalized patients

- Results not adjusted for patient baseline characteristics

- Partly reported adverse events

- Partly reported clinical

decision-making and outcomes
} 
Table 2. (continued)

\begin{tabular}{|c|c|c|c|c|c|}
\hline $\begin{array}{l}\text { Author, year, } \\
\text { study design, } \\
\text { country }\end{array}$ & Dates & $\begin{array}{l}\text { Number } \\
\text { of cases }\end{array}$ & Patient characteristics & Results & $\begin{array}{l}\text { Quality assessment and } \\
\text { major limitations }\end{array}$ \\
\hline & & & $\begin{array}{l}\text { diabetes mellitus, and } \\
\text { coronary artery disease } \\
\text { Case 2: 59-year-old fe- } \\
\text { male with hypertension } \\
\text { Case 3: 49-year-old male } \\
\text { with no known medical } \\
\text { history }\end{array}$ & $\begin{array}{l}\text { - Case } 1 \text { : transient improvement } \\
\text { in } \mathrm{PaO} 2 / \mathrm{FiO} 2(\mathrm{P} / \mathrm{F}) \text { ratio but } \\
\text { died } 3 \text { days later } \\
\text { - Case } 2: \text { slight improvement in } \\
\mathrm{P} / \mathrm{F} \text { ratio } 90 \text { to } 135 \text { after } 3 \text { days } \\
\text { - Case 3: transient improvement } \\
\text { in } \mathrm{P} / \mathrm{F} \text { ratio, requiring proning }\end{array}$ & \\
\hline
\end{tabular}

a day (8000 IU twice a day if body mass index was $>35 \mathrm{~kg} /$ $\mathrm{m}^{2}$ ), antithrombin concentrate to correct values $<70 \%$, and a clopidogrel loading dose of $300 \mathrm{mg}$ plus $75 \mathrm{mg}$ /day if platelet counts were $>400,000$ cells $/ \mu \mathrm{L} .{ }^{32}$ The primary objective of this study was to characterize the coagulation profile of patients with COVID-19 and ARDS, but the study also reports that no major thromboembolic events were observed after patients were treated with this protocol. At the end of the study period, 7 patients had died, 6 were extubated and transferred to the ward, and 3 remained in intensive care. Harms related to thromboprophylaxis are not reported. Without a comparison group or more information about patients' baseline characteristics or clinical course, the study cannot be used to evaluate the potentials benefits and risks of this thromboprophylaxis strategy but does provide a basis for a controlled trial.

In a case series of 3 critically ill, mechanically ventilated patients with COVID-19 and ARDS who received tPA followed by heparin, $\mathrm{PaO} 2 / \mathrm{FiO} 2$ (P/F ratio, a measure of ARDS severity with a lower number representing more severe disease) improved in all 3 patients but this improvement was transient in at least 2 patients. ${ }^{27}$ No patients had apparent bleeding complications. One of the patients included in the report died but clinical outcomes were not reported for the other 2 patients aside from $\mathrm{P} / \mathrm{F}$ ratio and whether the patients required prone positioning. While tPA and heparin doses are described, the study does not include information on the criteria for starting and stopping IPA and heparin or a protocol on the timing of $\mathrm{P} / \mathrm{F}$ measurements. Overall, the report has variable direction of results and inconsistent reporting of clinical outcomes. Further study with a controlled trial would be needed to evaluate the risks and benefits of this treatment strategy.

Overall, we have very low confidence in these findings due to methodological limitations of the studies (high risk of bias due to potential confounders and inconsistent patient followup), low applicability to treatment settings where thromboprophylaxis is standard of care, and inconsistent results. The 3 studies we identified examining patient outcomes with antithrombotic therapies all included different interventions (thromboprophylaxis with UFH or LMWH; an intensive thromboprophylaxis protocol with LMWH, antithrombin, and clopidogrel; and salvage therapy with IPA and heparin). Any estimate of effect based on these individual studies is very uncertain. It is very likely that future larger studies will have different findings.

\section{DISCUSSION}

The aim of this rapid systematic review was to synthesize evidence on the incidence of thromboembolism in patients with COVID-19 and whether antithrombotic therapies improve outcomes. Overall, we identified a small number of studies, each with serious methodological limitations or inadequate reporting. This new evidence on thromboembolism in COVID-19 does not warrant a change in current guidance on thromboprophylaxis among acutely and critically ill hospitalized patients.

Importantly, these early studies of thromboembolism in COVID-19 disease serve to highlight low rates of thromboprophylaxis use in certain settings and regions. In a large retrospective study of 1026 patients with COVID-19 in China, information about anticoagulation use was available for only 140 patients and among these patients only $7 \%$ (10 patients) had received anticoagulant drugs during their hospitalization. ${ }^{8}$ Findings from this study and others cited above suggest that greater implementation of evidence-based, guidelineconcordant thromboprophylaxis strategies (i.e., use of LMWH and UFH) in hospitalized patients is a practical step that clinicians can take now to improve care for patients with COVID-19.

Limitations of this review include our use of sequential rather than independent dual review processes for study selection, data abstraction, and quality assessment in order to accommodate a compressed timeline. This streamlined process could have resulted in missing eligible studies or data, although we made attempts to reduce this risk by establishing explicit inclusion criteria for studies and using a standard table for data abstraction. Given the rapid rate of new evidence being released on patients with COVID-19, it is also possible that relevant studies have been published since the end of our search date.

In conclusion, questions remain regarding the incidence of thromboembolism among patients with COVID-19 compared to other causes of sepsis and critical illness. It is also unknown whether patients with COVID-19 should be treated with different thromboprophylaxis protocols than those previously recommended for hospitalized patients. Prospective studies of antithrombotic therapies for hospitalized patients with COVID-19 are urgently needed and several studies are planned (Table 3.) In the meantime, the WHO and 
Table 3 Ongoing/Planned Clinic Trials on Thromboembolism in COVID-19 Disease and Management

\begin{tabular}{|c|c|c|c|c|c|c|}
\hline Agent & Sponsor & Title & $\begin{array}{l}\text { ClinicalTrials. } \\
\text { gov identifier } \\
\text { and date } \\
\text { registered }\end{array}$ & Study type & Primary outcome & $\begin{array}{l}\text { Secondary } \\
\text { outcome(s) }\end{array}$ \\
\hline $\begin{array}{l}\text { Aspirin } 75 \mathrm{mg} \text {, } \\
\text { clopidogrel } 75 \mathrm{mg}, \\
\text { rivaroxaban } 2.5 \\
\mathrm{mg} \text {, atorvastatin } \\
40 \mathrm{mg} \text {, } \\
\text { omeprazole } 20 \mathrm{mg}\end{array}$ & $\begin{array}{l}\text { Imperial College } \\
\text { London }\end{array}$ & $\begin{array}{l}\text { Preventing cardiac } \\
\text { complication of } \\
\text { COVID-19 disease } \\
\text { with early acute coro- } \\
\text { nary syndrome therapy: } \\
\text { a randomised con- } \\
\text { trolled trial }\end{array}$ & $\begin{array}{l}\text { NCT04333407; } \\
04 / 03 / 2020^{33}\end{array}$ & Interventional & $\begin{array}{l}\text { All-cause } \\
\text { mortality at } 30 \\
\text { days after } \\
\text { admission }\end{array}$ & $\begin{array}{l}\text { Absolute change in } \\
\text { serum troponin } \\
\text { from admission to } \\
\text { peak value, } \\
\text { discharge rate, } \\
\text { intubation rate. }\end{array}$ \\
\hline Defibrotide & $\begin{array}{l}\text { IRCCS San } \\
\text { Raffaele } \\
\text { Scientific } \\
\text { Institute }\end{array}$ & $\begin{array}{l}\text { Use of defibrotide to } \\
\text { reduce progression of } \\
\text { acute respiratory failure } \\
\text { rate in patients with } \\
\text { COVID-19 pneumonia }\end{array}$ & $\begin{array}{l}\text { NCT04335201; } \\
04 / 06 / 2020^{34}\end{array}$ & Interventional & $\begin{array}{l}\text { Eval progression } \\
\text { to acute } \\
\text { respiratory failure }\end{array}$ & $\begin{array}{l}\text { Adverse events, } \\
\text { duration of } \\
\text { hospitalization, } \\
\text { systemic } \\
\text { inflammation, } \\
\text { overall survival }\end{array}$ \\
\hline NA & Jessa Hospital & $\begin{array}{l}\text { COVID-19 and deep } \\
\text { venous thrombosis: a } \\
\text { cross-sectional study }\end{array}$ & $\begin{array}{l}\text { NCT04338932; } \\
04 / 08 / 2020^{35}\end{array}$ & Observational & $\begin{array}{l}\text { Prevalence and } \\
\text { possible risk } \\
\text { factors for DVT in } \\
\text { ICU }\end{array}$ & None \\
\hline NA & $\begin{array}{l}\text { University } \\
\text { Hospital of } \\
\text { Ferrara }\end{array}$ & $\begin{array}{l}\text { Prothrombotic status in } \\
\text { patients with SARS- } \\
\text { CoV-2 infection } \\
\text { (ATTAC-Co) }\end{array}$ & $\begin{array}{l}\text { NCT04343053; } \\
04 / 13 / 2020^{36}\end{array}$ & Interventional & $\begin{array}{l}\text { Diagnostics: } \\
\text { several markers of } \\
\text { platelet, } \\
\text { coagulation, and } \\
\text { endothelial } \\
\text { function }\end{array}$ & $\begin{array}{l}\text { Change in } \\
\text { laboratory tests and } \\
\text { clinical status }\end{array}$ \\
\hline $\begin{array}{l}\text { Enoxaparin or } \\
\text { unfractionated } \\
\text { heparin }\end{array}$ & $\begin{array}{l}\text { University } \\
\text { Hospital, Geneva }\end{array}$ & $\begin{array}{l}\text { Preventing COVID-19 } \\
\text { complications with } \\
\text { low- and High-dose } \\
\text { anticoagulation } \\
\text { (COVID-HEP) }\end{array}$ & $\begin{array}{l}\text { NCT04345848; } \\
04 / 15 / 2020^{37}\end{array}$ & Interventional & $\begin{array}{l}\text { Composite } \\
\text { outcome of } \\
\text { arterial or venous } \\
\text { thrombosis, } \\
\text { disseminated } \\
\text { intravascular } \\
\text { coagulation and } \\
\text { all-cause mortality }\end{array}$ & $\begin{array}{l}\text { Adverse events, } \\
\text { clinical worsening, } \\
\text { duration of } \\
\text { hospitalization, } \\
\text { overall survival }\end{array}$ \\
\hline Defibrotide & $\begin{array}{l}\text { Fundacion para } \\
\text { la Formacion e } \\
\text { Investigacion } \\
\text { Sanitarias de la } \\
\text { Region de } \\
\text { Murcia }\end{array}$ & $\begin{array}{l}\text { Defibrotide as } \\
\text { prevention and } \\
\text { treatment of respiratory } \\
\text { distress and cytokine } \\
\text { release syndrome of } \\
\text { COVID } 19 . \\
\text { (DEFACOVID) }\end{array}$ & $\begin{array}{l}\text { NCT04348383; } \\
04 / 16 / 2020^{38}\end{array}$ & Interventional & $\begin{array}{l}\text { All-cause } \\
\text { mortality at } 30 \\
\text { days }\end{array}$ & $\begin{array}{l}\text { Change in clinical } \\
\text { status, } \\
\text { inflammatory } \\
\text { markers, imaging }\end{array}$ \\
\hline $\begin{array}{l}\text { Rivaroxaban } \\
\text { (Substudy A) }\end{array}$ & $\begin{array}{l}\text { Medical } \\
\text { University of } \\
\text { Vienna }\end{array}$ & $\begin{array}{l}\text { Austrian CoronaVirus } \\
\text { Adaptive Clinical Trial } \\
\text { (ACOVACT) }\end{array}$ & $\begin{array}{l}\text { NCT04351724; } \\
04 / 17 / 2020^{39}\end{array}$ & Interventional & $\begin{array}{l}\text { Clinical } \\
\text { improvement }\end{array}$ & $\begin{array}{l}\text { Change in clinical } \\
\text { status, } \\
\text { inflammatory } \\
\text { mortality }\end{array}$ \\
\hline $\begin{array}{l}\text { Tinzaparin or } \\
\text { unfractionated } \\
\text { heparin }\end{array}$ & $\begin{array}{l}\text { Assistance } \\
\text { Publique - } \\
\text { Hôpitaux de } \\
\text { Paris }\end{array}$ & $\begin{array}{l}\text { Trial evaluating } \\
\text { efficacy and safety of } \\
\text { anticoagulation in } \\
\text { patients with COVID- } \\
19 \text { infection, nested in } \\
\text { the Corimmuno-19 } \\
\text { Cohort } \\
\text { (CORIMMUNO- } \\
\text { COAG) }\end{array}$ & $\begin{array}{l}\text { NCT04344756; } \\
04 / 18 / 2020^{40}\end{array}$ & Interventional & $\begin{array}{l}\text { Survival without } \\
\text { ventilation and } \\
\text { ventilator free } \\
\text { survival }\end{array}$ & $\begin{array}{l}\text { Adverse events, } \\
\text { clinical worsening, } \\
\text { duration of } \\
\text { hospitalization, } \\
\text { overall survival }\end{array}$ \\
\hline $\begin{array}{l}\text { Alteplase } \\
\text { [Activase] }\end{array}$ & $\begin{array}{l}\text { Denver Health } \\
\text { and Hospital } \\
\text { Authority }\end{array}$ & $\begin{array}{l}\text { Study of alteplase for } \\
\text { respiratory failure in } \\
\text { SARS-Cov2 (COVID- } \\
\text { 19) (STARS) }\end{array}$ & $\begin{array}{l}\text { NCT04357730; } \\
04 / 22 / 2020^{41}\end{array}$ & Interventional & $\mathrm{PaO} 2 / \mathrm{FiO} 2$ ratio & $\begin{array}{l}\text { Changes in clinical } \\
\text { status }\end{array}$ \\
\hline $\begin{array}{l}\text { Nebulized version } \\
\text { tissue } \\
\text { plasminogen } \\
\text { activator (rt-PA) }\end{array}$ & $\begin{array}{l}\text { University } \\
\text { College, London }\end{array}$ & $\begin{array}{l}\text { Nebulised Rt-PA for } \\
\text { ARDS due to COVID- } \\
19 \text { (PACA) }\end{array}$ & $\begin{array}{l}\text { NCT04356833; } \\
04 / 22 / 2020^{42}\end{array}$ & Interventional & $\begin{array}{l}\mathrm{PaO} 2 / \mathrm{FiO} 2 \text { ratio, } \\
\text { adverse events, } \\
\text { fibrinogen levels }\end{array}$ & $\begin{array}{l}\text { Changes in clinical } \\
\text { status }\end{array}$ \\
\hline NA & $\begin{array}{l}\text { Centre } \\
\text { Hospitalier } \\
\text { Universitaire de } \\
\text { Nimes }\end{array}$ & $\begin{array}{l}\text { Analysis of the } \\
\text { coagulopathy } \\
\text { developed by COVID- } \\
19 \text { infected patients: } \\
\text { thrombin generation } \\
\text { potential in COVID-19 } \\
\text { infected patients }\end{array}$ & $\begin{array}{l}\text { NCT04356950; } \\
04 / 22 / 2020^{43}\end{array}$ & Observational & $\begin{array}{l}\text { Survival rate, } \\
\text { thrombin } \\
\text { generation tests } \\
\text { (latent period, } \\
\text { initial velocity, } \\
\text { peak thrombin, } \\
\text { total thrombin } \\
\text { generation time) }\end{array}$ & $\begin{array}{l}\text { Transfer to ICU, } \\
\text { thrombotic } \\
\text { complication, D- } \\
\text { dimer, soluble fi- } \\
\text { brin monomers }\end{array}$ \\
\hline $\begin{array}{l}\text { Tissue } \\
\text { plasminogen } \\
\text { activator (tPA) }\end{array}$ & $\begin{array}{l}\text { Beth Israel } \\
\text { Deaconess } \\
\text { Medical Center }\end{array}$ & NR & Not registered ${ }^{44}$ & Interventional & NR & NR \\
\hline
\end{tabular}


professional societies recommend adherence to previously established, evidence-based guidelines regarding thromboprophylaxis in hospitalized patients.

Acknowledgments: The authors thank Kathryn Vela, MLIS, AHIP for conducting the literature search and Payten Sonnen, BS for editorial assistance and citation management. We also thank Adam Obley, $M D$, for reviewing a draft of this manuscript.

Corresponding Author: Katherine Mackey, MD, MPP; Department of Veterans Affairs Evidence Synthesis Program (ESP), VA Portland Healthcare System, Portland, OR, USA (e-mail: katherine. mackey@va.gov).

Author Contributions This manuscript has been read and approved for submission by all authors. All authors conceived of the review. EM and DT conducted the first abstract review, which was verified by KM. $D T$ and EM reviewed the full text, extracted the data, and performed quality assessment. All authors contributed to the strength of evidence assessment and to the writing of the manuscript.

\section{Compliance with Ethical Standards:}

Conflict of Interest: The authors declare that they do not have a conflict of interest.

Disclaimer: The views expressed in this article are those of the authors and do not necessarily represent the views of the Department of Veterans Affairs or the US Government.

\section{REFERENCES}

1. Han $\mathbf{H}$, Yang $\mathbf{L}$, Liu $\mathbf{R}$, et al. Prominent changes in blood coagulation of patients with SARS-CoV-2 infection. [published online ahead of print, 2020 Mar 16]. Clin Chem Lab Med 2020;/j/cclm.ahead-of-print/cclm2020-0188/cclm-2020-0188.xml.

2. Driggin E, Madhavan Mv, Bikdeli B, et al. Cardiovascular considerations for patients, health care workers, and health systems during the coronavirus disease 2019 (COVID-19) pandemic. J Am Coll Cardiol. 2020;75(18):2352-2371

3. Tang $\mathbf{N}$, Li $\mathbf{D}$, Wang $\mathbf{X}$, Sun $\mathbf{Z}$. Abnormal coagulation parameters are associated with poor prognosis in patients with novel coronavirus pneumonia. J Thromb Haemost 2020; 18(4):844-847.

4. Hotchkiss RS, Moldawer LL, Opal SM, Reinhart K, Turnbull IR, Vincent J-L. Sepsis and septic shock. Nat Rev Dis Primers 2016;2(1): 16045 .

5. Ding $\mathbf{Y}$, Wang $\mathbf{H}$, Shen $\mathbf{H}$, et al. The clinical pathology of severe acute respiratory syndrome (SARS): a report from China. $J$ Pathol 2003;200(3):282-289

6. Yin $\mathbf{S}$, Huang $\mathbf{M}, \mathbf{L i} \mathbf{D}$, Tang $\mathbf{N}$. Difference of coagulation features between severe pneumonia induced by SARS-CoV2 and non-SARS-CoV2. $J$ Thromb Thrombolysis 2020;1-4.

7. Hunt J. Webinar: thrombosis, thromboprophylaxis \& coagulopathy in COVID-19 infections. https://academy.isth.org/isth/2020/covid-19/ 291581/marcel.levi.26.beverley.jane.hunt.webinar.thrombosis.thromboprophylaxis. $26 . \mathrm{html}$ ?f=menu\%3D8\%2Abrowseby\%3D8\%2Asortby\%3D2\%2Alabel\%3D 19794. Published 2020. Accessed April 13, 2020.

8. Wang T, Chen R, Liu C, et al. Attention should be paid to venous thromboembolism prophylaxis in the management of COVID-19. Lancet Haematol 2020;7(5):e362-e363.

9. Moore HB, C; Moore, $\mathbf{C}$; et al. Is there a role for tissue plasminogen activator (tPA) as a novel treatment for refractory COVID-19 associated acute respiratory distress syndrome (ARDS)? [published online ahead of print, 2020 Mar 20]. J Trauma Acute Care Surg 2020; https://doi.org/10. $1097 /$ TA.0000000000002694.

10. Marietta M, Ageno W, Artoni A, et al. COVID-19 and haemostasis: a position paper from Italian Society on Thrombosis and Haemostasis (SISET). Blood Transfus. 2020;08:08.

11. Clinical management of severe acute respiratory infection (SARI) when COVID-19 disease is suspected. WHO/2019-nCoV/clinical/2020.4. World Health Organization;2020.
12. Interim clinical guidance for management of patients with confirmed coronavirus disease (COVID-19). https://www.cdc.gov/coronavirus/ 2019-ncov/hcp/clinical-guidance-management-patients.html. Published 2020. Updated April 13, 2020. Accessed April 13, 2020.

13. Matos R; Chung K. DoD COVID-19 practice management guide: clinical management of COVID-19. DoD. https://asprtracie.hhs.gov/technicalresources/resource/7899/dod-covid-19-practice-management-guideclinical-management-of-covid-19. Published 2020. Updated March 23, 2020. Accessed April 13, 2020

14. Thachil J, Tang N, Gando S, et al. ISTH interim guidance on recognition and management of coagulopathy in COVID-19. $J$ Thromb Haemost 2020;18(5):1023-1026.

15. Schünemann HJ, Cushman M, Burnett AE, et al. American Society of Hematology 2018 guidelines for management of venous thromboembolism: prophylaxis for hospitalized and nonhospitalized medical patients. Blood Advan 2018;2(22):3198-3225.

16. Bikdeli B, Madhavan MV, Jimenez D, et al. COVID-19 and thrombotic or thromboembolic disease: implications for prevention, antithrombotic therapy, and follow-up. J Am Coll Cardiol 2020;15:15.

17. Tao DL, Bien JY, DeLoughery TG, Shatzel JJ. Extended thromboprophylaxis with direct oral anticoagulants for medical patients: a systematic review and meta-analysis. Blood. 2017;129(5):653-655

18. Rhodes A, Evans LE, Alhazzani W, et al. Surviving sepsis campaign: international guidelines for management of sepsis and septic shock: 2016. Intensive Care Med 2017;43(3):304-377.

19. Bhimraj A, Morgan RL, Shumaker AH, et al. Infectious Diseases Society of America Guidelines on the Treatment and Management of Patients with COVID-19. Infectious Diseases Society of America https://www. idsociety.org/practice-guideline/covid-19-guideline-treatment-and-management. Published 2020. Updated April 11, 2020. Accessed April 13, 2020.

20. Tao D, Maldonado E, and Mackey $\mathbf{K}$. Antithrombotic Therapies for COVID-19 Disease. Washington, DC: Evidence Synthesis Program, Health Services Research and Development Service, Office of Research and Development, Department of Veterans Affairs. VA ESP Project \#09199; 2020.

21. Berkman ND, Lohr KN, Ansari M, et al. AHRQ methods for effective health care grading the strength of a body of evidence when assessing health care interventions for the effective health Care program of the agency for healthcare research and quality: an update. In: Methods Guide for Effectiveness and Comparative Effectiveness Reviews. Rockville (MD): Agency for Healthcare Research and Quality (US); 2008.

22. Stewart LA, Clarke M, Rovers M, et al. Preferred Reporting Items for a Systematic Review and Meta-Analysis of individual participant data: the PRISMA-IPD statement. JAMA. 2015;313(16):1657-1665.

23. Sterne JA, Hernán MA, Reeves BC, et al. ROBINS-I: a tool for assessing risk of bias in non-randomised studies of interventions. Bmj. 2016;355:i4919.

24. Case report guidelines. 2013 CARE Checklist. https://www.care-statement.org/resources/checklist. Published 2013. Updated 2013. Accessed April 192020

25. Balshem $\mathbf{H}$, Helfand $\mathbf{M}$, Schünemann $\mathbf{H J}$, et al. GRADE guidelines: 3 . Rating the quality of evidence. J Clin Epidemiol 2011;64(4):401-406.

26. Cui S, Chen S, Li X, Liu S, Wang F. Prevalence of venous thromboembolism in patients with severe novel coronavirus pneumonia [published online ahead of print, 2020 Apr 9]. J Thromb Haemost 2020; https://doi. org $/ 10.1111 /$ jth. 14830

27. Wang $\mathbf{J}$, Hajizadeh $\mathbf{N}$, Moore EE, et al. Tissue plasminogen activator (tPA) treatment for COVID-19 associated acute respiratory distress syndrome (ARDS): a case series. J Thromb Haemost 2020; https://doi. org/10.1111/jth.14828.

28. Chen J, Wang, Xiang, Zhang, Shutong, Liu, Bin, Wu, Xiaoqing, Wang, Yanfang, Wang, Xiaoqi, Yang, Ming, Sun, Jianqing, Xie, Yuanliang. Findings of acute pulmonary embolism in COVID-19 patients. Available at SSRN: https://ssrn.com/abstract=3548771. Published 2020. Updated March 1, 2020. Accessed April 13, 2020.

29. Klok FA, Kruip M, van der Meer NJM, et al. Incidence of thrombotic complications in critically ill ICU patients with COVID-19. [published online ahead of print, 2020 Apr 10]. Thromb Res 2020; S00493848(20)30120-1.

30. Tang N, Bai H, Chen X, Gong J, Li D, Sun Z. Anticoagulant treatment is associated with decreased mortality in severe coronavirus disease 2019 patients with coagulopathy. $J$ Thromb Haemost 2020; 18(5): 1094-1099.

31. Marone EM, Rinaldi LF. Upsurge of deep venous thrombosis in patients affected by COVID-19: preliminary data and possible explanations. $J$ Vasc Surg Venous Lymphat Disord 2020;S2213-333X(20)30214-6. 
32. Ranucci M, Ballotta A, Di Dedda U, et al. The procoagulant pattern of patients with COVID-19 acute respiratory distress syndrome. $J$ Thromb Haemost 2020; https://doi.org/10.1111/jth. 14854.

33. Preventing cardiac complication of COVID-19 disease with early acute coronary syndrome therapy: a randomised controlled trial. ClinicalTrials. gov Identifier: NCT04333407. https://clinicaltrials.gov/ct2/show/ NCT04333407?term=Preventing+Cardiac+Complication+of+COVID19+Disease+With+Early+Acute+Coronary+Syndrome+Therapy $\% 3 A+A+R-$ andomised + Controlled + Trial. $\&$ recrs $=$ ab $\& d r a w=2 \&$ rank $=1$. Published 2020. Updated April 9, 2020 Accessed April 24, 2020.

34. Use of defibrotide to reduce progression of acute respiratory failure rate in patients with COVID-19 pneumonia. ClinicalTrials.gov Identifier: NCT04335201. https://clinicaltrials.gov/ct2/show/NCT04335201?ter$\mathrm{m}=$ Use+of+Defibrotide+to+Reduce+Progression+of+Acute+Respiratory+Failure+Rate+in+Patients+With+COVID-19+Pneumonia\&draw=2\&rank=1 Published 2020. Updated April 6, 2020. Accessed April 24, 2020

35. COVID-19 and deep venous thrombosis. ClinicalTrials.gov Identifier: NCT04338932 https://clinicaltrials.gov/ct2/show/NCT04338932? term $=$ NCT04338932\&draw $=2 \& r a n k=1$. Published 2020. Updated April 8, 2020. Accessed April 24, 2020.

36. Pro-thrombotic status in patients with SARS-CoV-2 infection (ATTAC-Co). ClinicalTrials.gov Identifier: NCT04343053 https://clinicaltrials.gov/ct2/ show/NCT04343053?term=Pro-thrombotic+Status+in+Patients+with+SARS-CoV-2+Infection+\%28ATTAC-Co\%29\&draw=2\&rank=1. Updated April 13. Accessed April 24, 2020.

37. Preventing COVID-19 complications with low- and high-dose anticoagulation (COVID-HEP). ClinicalTrials.gov Identifier: NCTO4345848. https:// clinicaltrials.gov/ct2/show/NCT04345848?term=NCT04345848\&dra$\mathrm{w}=2 \&$ rank=1. Published 2020. Updated April 15, 2020. Accessed April $24,2020$.

38. Defibrotide as prevention and treatment of respiratory distress and cytokine release syndrome of COVID 19. (DEFACOVID). ClinicalTrials. gov Identifier: NCT04348383 https://clinicaltrials.gov/ct2/show/ NCT04348383?term=Defibrotide+as+Prevention+and+Treatment+of+Respiratory+Distress+and+Cytokine+Release+Syndrome+of+Covid+19. $+\% 28$ DEFACOVID\%29\&draw=2\&rank=1. Published 2020. Updated April 27, 2020. Accessed April 24, 2020.
39. Austrian CoronaVirus Adaptive Clinical Trial (ACOVACT). ClinicalTrials.gov Identifier: NCT04351724. https://clinicaltrials.gov/ct2/show/ NCT04351724?term=Austrian+CoronaVirus+Adaptive+Clinical+Tria1+\%28ACOVACT\%29\&draw $=2 \&$ rank $=1$. Published 2020. Updated April 24, 2020. Accessed April 24, 2020.

40. Trial evaluating efficacy and safety of anticoagulation in patients with COVID-19 infection, nested in the Corimmuno-19 Cohort (CORIMMUNOCOAG). ClinicalTrials.gov Identifier: NCT04344756. https://clinicaltrials. gov/ct $2 /$ show/NCT04344756?term=NCT04344756\&draw=2\&rank=1. Published 2020. Updated April 15, 2020. Accessed April 24, 2020, 2020.

41. Study of alteplase for respiratory failure in SARS-Cov2 (COVID-19) (STARS). ClinicalTrials.gov Identifier: NCTO4357730. https://clinicaltrials.gov/ct2/show/NCT04357730?term=Study+of+Alteplase+for+Respiratory+Failure+in+SARS-Cov2+\%28COVID-19\%29+\%28STARS\%29\&draw $=2 \&$ rank=1. Published 2020. Updated April 24, 2020. Accessed April 24, 2020.

42. Nebulised Rt-PA for ARDS due to COVID-19 (PACA). ClinicalTrials.gov Identifier: NCT04356833. https://clinicaltrials.gov/ct2/show/ NCT04356833?term=Nebulised+Rt-PA+for+ARDS+Due+to+COVID19+\%28PACA\%29\&draw=2\&rank=1. Published 2020. Updated April 22, 2020. Accessed April 24, 2020.

43. Analysis of the coagulopathy developed by COVID-19 infected patients: thrombin generation potential in COVID-19 infected patients. ClinicalTrials.gov Identifier: NCT04356950 https://clinicaltrials.gov/ct2/show/ NCT04356950?term=Analysis+of+the+Coagulopathy+Developed+by+COVID-19+Infected+Patients\%3A+Thrombin+Generation+Potential+in+COVID-19+Infected+Patients\&draw=2\&rank=1. Published 2020. Updated April 22. Accessed April 24, 2020.

44. Stephenson K. tPA-COVID-19. Boston Clinical Trials. https://collaborate.hms.harvard.edu/display/covid19/tPA+Study. Published 2020. Updated April 5, 2020. Accessed April 13, 2020.

Publisher's Note: Springer Nature remains neutral with regard to jurisdictional claims in published maps and institutional affiliations. 